\title{
Current standing and frontiers of gene therapy for meningiomas
}

\author{
Rafael De la Garza-Ramos, M.D., ${ }^{1}$ Jessica V. Flores-Rodríguez, M.D., ${ }^{1}$ \\ Juan Carlos Martínez-Gutiérrez, M.D., ${ }^{1}$ Alejandro Ruiz-Valls, M.D.,2 \\ and Enrique Caro-Osorio, M.D. ${ }^{1,3}$
}

${ }^{1}$ Tecnológico de Monterrey School of Medicine and Health Sciences; ${ }^{3}$ Institute of Neurology and Neurosurgery, Hospital Zambrano Hellion, Tec Salud, Monterrey, Nuevo León, México; and ${ }^{2}$ Universidad de Valencia, Facultad de Medicina y Odontología, Valencia, Spain

\begin{abstract}
Meningiomas are among the most common intracranial tumors. The treatment of choice for these lesions is complete resection, but in 50\% of cases it is not achieved due to tumor location and/or surgical morbidities. Moreover, benign meningiomas have high recurrence rates of up to $32 \%$ in long-term follow-up. Molecular analyses have begun to uncover the genetics behind meningiomas, giving rise to potential genetics-based treatments, including gene therapy. The authors performed a literature review on the most relevant genes associated with meningiomas and both current and potential gene therapy strategies to treat these tumors. Wild-type NF2 gene insertion, oncolytic viruses, and transfer of silencing RNA have all shown promising results both in vitro and in mice. These strategies have decreased meningioma cell growth, proliferation, and angiogenesis. However, no clinical trial has been done to date. Future research and trials in gene insertion, selective inhibition of oncogenes, and the use of oncolytic viruses, among other potential treatment approaches, may shape the future of meningioma management. (http://thejns.org/doi/abs/10.3171/2013.8.FOCUS13305)
\end{abstract}

KeY WORDS • meningioma • gene therapy $\bullet$ genetics $\bullet$ neurosurgery

M ENINGIOMAS are typically slow-growing tumors of the central nervous system (CNS) that originate from arachnoid cap cells, which belong to the outermost layer of the arachnoid mater. Meningiomas are the second most common primary adult neoplasm of the CNS after glioblastoma multiforme (GBM), with an annual estimated incidence of 2.3 cases per 100,000 persons. $^{71,72}$ Most of these tumors are considered benign, but although 5-year survival rates reach $90 \%, 20$-year survival rates are approximately 53\% ${ }^{80}$ Intracranial meningiomas represent $98 \%$ of all CNS meningiomas (spinal lesions denote approximately $2 \%$ of cases). ${ }^{31}$ Several risk factors have been associated with the development of these tumors, among them female sex, hormone-replacement therapy, advanced age, deletions of the neurofibromin 2 (NF2) gene, ionizing radiation, and head trauma. . $^{8,16,26,36}$ Meningiomas are more commonly sporadic, yet they can be hereditary in patients with neurofibromatosis Type 2 , multiple endocrine neoplasia Type 1, or Li-Fraumeni, Turcot, Gardener, von Hippel-Lindau, Cowden, or Gorlin syndrome. ${ }^{38}$

\footnotetext{
Abbreviations used in this paper: $\mathrm{Ad}=$ adenovirus; $\mathrm{GBM}=$ glioblastoma multiforme; GWAS = genome-wide association study; $\mathrm{HSV}=$ herpes simplex virus; siRNA = small interfering RNA.
}

The current standard of care for patients with meningiomas is gross-total resection of the tumor, ${ }^{37} \mathrm{a}$ feat that is sometimes difficult to achieve due its location and/or surgical morbidities. Hence, complete resection is achieved in less than $50 \%$ of patients, ${ }^{27}$ and recurrence rates in macroscopically complete tumor removal (Simpson Grades 1-3) are up to $32 \%$ after 15 years of follow-up. ${ }^{80}$ On the other hand, radiation-based treatments and chemotherapy have potential benefits for patients with these neoplasms, but the role of these therapeutic approaches in the management of meningiomas is limited to cases of subtotal resection or when tumors are virtually inaccessible due to their critical location..$^{12,47,66}$

Over the last years, there has been an increasing attention to the molecular genetics of meningiomas. Research has been focused on tumor-suppressor genes, oncogenes, and cell-signaling pathways, including their role on the development, aggressiveness, and recurrence of these tumors. ${ }^{3,16,51,65,75}$ The resulting information has led the way for an increasing interest in potential genetics-based treatments. These novel procedures, particularly gene therapy, aim to treat meningiomas by genetically modifying the cancerous cells ${ }^{76}$ Neurosurgeons must recognize the importance of knowing the principles behind genetics-based treatments and their potential therapeutic benefits, in as 


\section{R. De la Garza-Ramos et al.}

much as the future of medicine will tend toward less invasive, more selective and safer treatment options.

In this article, we first present a concise review of the genes currently known to be associated with the etiology and pathophysiology of intracranial meningiomas. We then describe the principles behind genetics-based treatments for neoplastic disorders, and finally focus on the current standing and frontiers of these treatments applied to meningiomas.

\section{Histopathology and Genetics of Meningiomas}

The World Health Organization (WHO) categorizes meningiomas into several grades based on cell type, mitotic activity, cellularity, necrosis, and brain invasion. The benign type (WHO Grade I) is the most common, representing $80 \%$ of all cases. This type is followed by atypical (WHO Grade II, 15\%-20\%) and anaplastic (WHO Grade III, $1 \%-3 \%$ ) meningiomas. ${ }^{71}$ Grade I tumors are histologically classified as meningothelial, fibrous, transitional, psammomatous, angiomatous, microcystic, secretory, lymphoplasmacyte-rich, or metaplastic. Grade II meningiomas are more aggressive and are classified as clear cell or choroidal. Grade III meningiomas are considered malignant and are divided into rhabdoid or papillary subtypes. ${ }^{53}$ Unfortunately, the specific molecular genetic basis for such diverse histological subtypes has not been yet determined. ${ }^{65}$

Tumor suppressor genes encode proteins that regulate and suppress cell proliferation by inhibiting progression of the cell throughout the cell cycle. Inactivation of tumor suppressor genes and consequently uncontrolled cell proliferation occurs when both alleles become nonfunctional, according to Knudson's two-hit hypothesis. ${ }^{48}$ The $N F 2^{83}$ and $C D K N 2 A^{9}$ genes are examples of tumor suppressor genes involved in meningiomas. Proto-oncogenes on the other hand encode proteins involved in regulation and promotion of cell growth and proliferation. These genes may suffer a change in their genetic sequence or a loss of regulation, thus creating oncogenes. Oncogenes will now uncontrollably promote cell proliferation and potentially cause neoplasia; $c$-sis $(P D G F B)^{56}$ and $c-m y c^{20}(M Y C)$ are examples of oncogenes involved in meningiomas.

Recently, a prostaglandin D synthase (PGDS)-positive meningeal cell has been identified as a possible precursor cell to meningiomas. Researchers found that the inactivation of NF2 in embryonic PGDS-positive cells was related to the heterogeneity of meningioma histological subtypes. ${ }^{43}$

\section{Genes Involved in Meningioma Tumorigenesis}

The main tumor suppressor gene involved in early meningioma tumorigenesis is $N F 2$ (Table 1). ${ }^{16,65}$ Alterations in the $N F 2$ gene are the most common cytogenetic abnormalities found in meningiomas; ${ }^{16}$ most neurofibromatosis Type 2 meningiomas and up to $78 \%$ of sporadic meningiomas have deletions in chromosome $22 \mathrm{q} .{ }^{68}$ This gene is found on chromosome $22 \mathrm{q}$ and encodes for a protein called merlin, whose main function is to link the cell membrane proteins to the cytoskeleton. Recent studies have revealed that merlin also plays a role as part of the actin cytoskeleton and is involved in the regulation of cell proliferation and growth and the initiation of neoplastic behavior. ${ }^{30,77}$

The $D A L-1$ gene has a debated role in meningioma tumorigenesis; it encodes for the $4.1 \mathrm{~B}$ protein, which belongs to the same superfamily as merlin. $4.1 \mathrm{~B}$ acts as a regulator of cell proliferation and apoptosis and has also been associated with tumor initiation, but to a much lesser extent than $N F 2 .{ }^{63}$

The main oncogenes involved in meningioma tumorigenesis are Ha-ras and $c$-mos. ${ }^{65}$ Their role in initiation of neoplastic behavior is yet much less understood than that of $N F 2 .{ }^{21,68}$

\section{Genes Involved in Meningioma Cell Growth}

The major genes involved in cell growth are oncogenes $c$-fos (FOS), c-myc (MYC), and $c$-sis (PDGFB) (Table 2). ${ }^{65,68} C$-fos and $c$-myc are nuclear transcriptionregulating genes; both are overexpressed in meningiomas, with research indicating a probable involvement in growth factor autocrine loop signaling. ${ }^{20,40} C$-sis is also overexpressed in meningiomas; it encodes a component of platelet-derived growth factor- $\beta$, suggesting a role in cell growth and maintenance. ${ }^{44,56}$

\section{Genes Involved in Higher Meningioma Grade}

The most important tumor suppressor genes associated with higher meningioma grade are TIMP1, TIMP3, $C D K N 2 A, C D K N 2 B, C D K N 2 A$ (p14[ARF]), and NDRG2 (Table 3). ${ }^{16}$ Tissue inhibitors of matrix metalloproteinases (TIMPs) have the task of regulating matrix metalloproteinase (MMP) activity, cellular proliferation and angiogenesis. ${ }^{28}$ Inactivation or lower activity of both TIMPI and TIMP3, mainly through methylation, has been associated with a more invasive and higher-grade meningioma idiosyncrasy. ${ }^{6,35}$ Chromosome 9 harbors the genes $C D K N 2 A$, $C D K N 2 B$, and $C D K N 2 A(p 14 A R F)$, All three are regulators of cell cycle progression at the G1/S phase checkpoint.$^{65}$ Complete losses of $9 p$ or more subtle homozygous deletions of these genes have been found in higher-grade meningiomas. ${ }^{9}$ Lastly, NDRG family member 2 (NDRG2, also known as $N$-Myc downstream-regulated gene 2) has been found to be downregulated in anaplastic and atypical meningiomas with aggressive behavior. ${ }^{54}$

The major oncogenes associated with higher meningioma grade are Bcl-2 (BCL2), STAT3, and TP73.65 All of these genes have been found to have higher expression rates in higher-grade meningiomas. ${ }^{1,88}$

\section{Cell Signaling Pathways}

Cell signaling pathways control various processes such as cell differentiation and proliferation. The Hedgehog and Wnt signaling pathways have been associated in the progression of meningiomas, ${ }^{65}$ and to a lesser extent the Notch, transforming growth factor- $\beta$, and insulin receptor signaling pathways have also been associated with these tumors. . $^{17,42,64,84}$

\section{The Principles Behind Genetics-Based Treatments for Cancer}

Gene therapy involves the artificial allocation of ge- 


\section{Genetics-based treatments for meningiomas}

TABLE 1: Major genes involved in meningioma tumorigenesis*

\begin{tabular}{|c|c|c|c|c|}
\hline Gene & Type & Locus & Encoded Protein & Function \\
\hline NF2 & TSG & $22 q 12.2$ & merlin & $\begin{array}{l}\text { cell membrane linkage to cytoskeleton; cell growth and prolifera- } \\
\text { tion }\end{array}$ \\
\hline DAL-1 (EPB41L3) & TSG & 18p11.32 & 4.1B protein & $\begin{array}{l}\text { cell membrane linkage to cytoskeleton; regulator of apoptosis \& } \\
\text { cell proliferation }\end{array}$ \\
\hline Ha-ras (HRAS) & oncogene & 11p15.5 & p21 & cyclin-dependent kinase inhibitor \\
\hline c-mos (MOS) & oncogene & $8 q 11$ & c-mos protein & serine kinase \\
\hline
\end{tabular}

* TSG = tumor suppressor gene.

netic material (complete genes or gene segments) into a host cell. General somatic gene therapy strategies include gene augmentation therapy, targeted killing of specific cells, and targeted inhibition of gene expression. ${ }^{76}$ Gene augmentation therapy is useful for diseases caused by loss of function of a gene. Direct cell killing is possible when inserted genes cause cellular apoptosis (suicide genes) or when the expressed gene increases susceptibility of the cell to be killed by a specific drug. Targeted mutation correction involves correction of resident mutations when they produce a dominant-negative effect, and lastly targeted inhibition of gene expression allows for selective blocking of single genes at the DNA, RNA, or protein level. ${ }^{76}$

Gene therapy aimed at treating neoplastic disorders also involves general approaches including artificial killing of cancer cells, stimulation of natural killing of cancer cells, use of oncolytic viruses (explained in Gene Therapy for Brain Tumors), and protecting the surrounding normal tissues from effects of chemotherapy/radiotherapy (Fig. 1). ${ }^{76}$

Patients with tumors arising from inactivation of tumor suppressor genes can benefit from gene augmentation therapy or from insertion of wild-type tumor suppressor genes. Patients with tumors resulting from oncogene activation may benefit from selective inhibition of gene expression, delivery of gene-specific ribozymes to cleave oncogene mRNA, or the use of intracellular antibodies to specifically bind to and inactivate the oncoprotein.

\section{Technology of Gene Therapy}

Gene transfer can occur outside or inside the patient's body. Ex vivo therapy involves the removal of target cells from a patient, growth in culture, genetic modification, and finally reimplantation of these cells into the host. This therapy is useful when target cells are accessible for removal and have long survival times after replacement. Such is the case for hematopoietic and skin cells. ${ }^{76}$ In vivo therapy involves the transfer of genetic material to target cells within the patient. This becomes the only option when target cells cannot be cultured in vitro in adequate numbers (as with brain cells) or when treated cells cannot be reimplanted effectively.

Once a specific strategy for the treatment of cancer has been chosen, the challenge now becomes how to deliver the genetic material to the cancer cell. Size of the DNA fragments is sometimes limited by the vector capacity, but this limitation can be circumvented by transferring small artificial minigenes. ${ }^{76}$ After the genes have been transferred to the host cell, the genetic material may integrate into the chromosome of the cell or remain as an extrachromosomal gene (episome). Integration of the gene into the chromosome has the advantage of perpetual and long-term expression through cell division. Nonetheless, insertion occurs randomly and therefore the gene may not be expressed at all or may even cause cell death. ${ }^{76}$ On the other hand, episomes may have a more stable expression rate, but long-term expression now becomes an issue because when cells divide; the newly introduced gene may segregate unequally to daughter cells.

The specific delivery system used in gene therapy depends on the target tissue, the size of the genetic material, and whether therapy is in vivo or ex vivo. Transfer of genetic material via viral vectors is called transduction, and this is the most commonly used method of delivery, ${ }^{81}$ because viral vectors are very effective in infecting cells, transferring genetic material, and inducing construct expression. The use of nonviral vectors is called transfection, and it usually involves naked DNA plasmids, lipoplexes (spherical vesicles composed of synthetic lipid bilayers), or other inorganic nanoparticles. ${ }^{82}$ Viral vectors have the advantage of having higher transduction efficiency and longer-term gene expression, but they are associated with immunogenicity, carcinogenicity, poor target cell specificity, gene size transfer limitation, and high costs..$^{10}$ Nonviral methods offer the ability to transfer larger genes and easy and safe preparation with no immunogenicity. Nonetheless, nonviral methods have lower efficiency and target gene expression than viral methods. ${ }^{19,50}$

Targeting of viruses or other vehicles to specific tissues also poses a challenge. ${ }^{24}$ Targeting can be done at the

TABLE 2: Major genes involved in meningioma cell growth

\begin{tabular}{cllll}
\hline \multicolumn{1}{c}{ Gene } & \multicolumn{1}{c}{ Type } & \multicolumn{1}{c}{ Locus } & \multicolumn{1}{c}{ Encoded Protein } & \multicolumn{1}{c}{ Function } \\
\hline$c$-fos (FOS) & oncogene & $14 q 24.3$ & c-fos protein & transcription factor; autocrine loop signaling \\
$c$-myc (MYC) & oncogene & $8 \mathrm{q} 24$ & $c$-myc protein & transcription factor; autocrine loop signaling \\
$c$-sis (PDGFB) & oncogene & $22 q 13.1$ & $\beta$-chain of PDGF- $\beta$ & growth factor \\
\hline
\end{tabular}


R. De la Garza-Ramos et al.

TABLE 3: Major genes involved in higher-grade meningiomas

\begin{tabular}{|c|c|c|c|c|}
\hline Gene & Type & Locus & Encoded Protein & Function \\
\hline TIMP1 & TSG & Xp11.3-p11.23 & metalloproteinase inhibitor 1 & $\begin{array}{l}\text { inhibits MMP-9; regulation of cellular proliferation \& } \\
\text { apoptosis; angiogenesis }\end{array}$ \\
\hline TIMP3 & TSG & $22 q 13.1$ & metalloproteinase inhibitor 3 & $\begin{array}{l}\text { inhibits MMP-9 \& MMP-2; regulation of cellular pro- } \\
\text { liferation \& apoptosis; angiogenesis }\end{array}$ \\
\hline CDKN2A & TSG & $9 p 21.3$ & p16 protein & cell cycle control \\
\hline CDKN2B & TSG & $9 p 21.3$ & p15 protein & cell cycle control \\
\hline CDKN2A $(p 14[A R F])^{*}$ & TSG & $9 p 21.3$ & p14arf protein & cell cycle control \\
\hline NDRG2 & TSG & $14 q 11.2$ & NDRG2 protein & growth \& apoptosis regulator \\
\hline$B C L 2$ & oncogene & $18 q 21.33$ & bcl-2 protein & apoptosis regulator \\
\hline STAT3 & oncogene & $17 q 21.2$ & signal transducer \& activator of transcript 3 & transcription factor \\
\hline TP73 & oncogene & $1 p 36.3$ & p73 & apoptosis factor \\
\hline
\end{tabular}

* Product of an alternate reading frame of CDKN2A.

level of virus cell binding and entry or after virus uptake. Entry targeting can be achieved through modifications of the outer virus membrane, thus granting the virus the ability of selective binding. Redirection of viruses to alternate cell surface molecules can also be attained by using specific adapter molecules and by insertion of ligands. ${ }^{34,62}$ Postentry targeting takes the form of transcriptional targeting, where mutations of specific viral genes create strains that are inefficient for replication in normal cells but efficient in cancerous cells. ${ }^{24}$

\section{Gene Therapy for Brain Tumors}

The use of gene therapy for brain tumors has been mostly focused on treatments for GBM utilizing viral vectors. . $^{2,18,41,61}$ Therapeutic viruses exist in the form of genetically engineered replication-competent or replication-incompetent viruses. The former function as oncolytic viruses, and the latter function solely as vectors. ${ }^{18}$ Oncolytic viruses selectively infect cancer cells, replicate within them, and cause cell lysis. ${ }^{15}$ Viruses currently investigated for use in brain cancer include herpes simplex viruses (HSVs), adenovirus (Ad), vaccinia virus, retrovirus, and others.

HSV-1 is a double-stranded DNA virus with a genome of approximately 80 genes $(152 \mathrm{~kb})$. Genetic alterations in the thymidine kinase gene $(T K),{ }^{55}$ ribonucleotide reductase ICP6/RR and/or ICP34.5/ $/ 34.5$, for example, restrict viral replication to rapidly dividing cells ${ }^{11,59,85}$ and create safer oncolytic viruses..$^{45,70}$ This modification prevents viral replication in normal brain tissue, preventing lifethreatening encephalitis. Deletion of essential immediate early genes (for example, ICP4 and ICP27) can render a replication-defective HSV-1, which can be used solely as a vehicle for delivery of therapeutic genetic material. ${ }^{60}$

Adenoviruses are also double-stranded linear DNA viruses but with a smaller genome $(36 \mathrm{~kb})$ compared with HSV. ${ }^{18}$ These viruses can be turned replication-incompetent by deletions in early regions of their genomes (E1A, $\mathrm{E} 1 \mathrm{~B}, \mathrm{E} 2, \mathrm{E} 3$, or E4) or through substitution of essential genes with a specific therapeutic gene of interest. ${ }^{7}$ Adenoviruses can be used to deliver tumor suppressor genes to cancerous cells (wild-type insertion of tumor suppressor gene) or prodrug activation enzymes such as the HSV-thymidine kinase. Delivery of wild-type $p 53$ to brain tumor cells has been tested, with evidence showing inhibition of glioma growth both in vitro and in vivo. ${ }^{49,58}$ Oncolytic adenoviruses are also emerging as an alternative therapy for patients with brain tumors. ${ }^{41}$

Vaccinia virus is an enveloped double-stranded DNA virus with a life cycle of less than 6 hours. ${ }^{18}$ This virus can

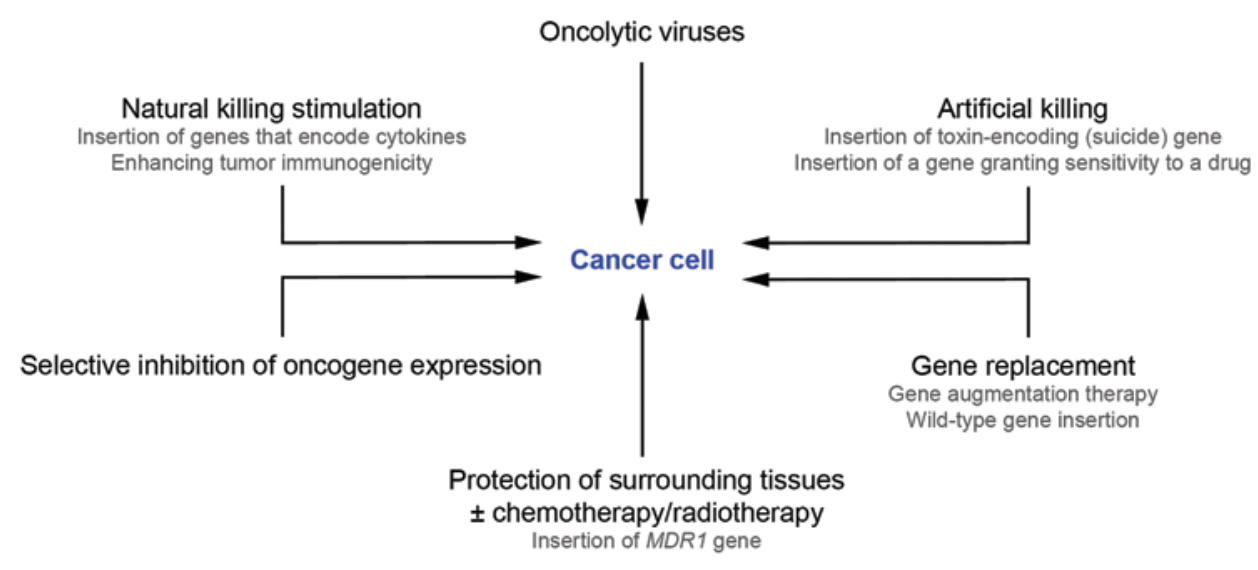

FıG. 1. General strategies of gene therapy for neoplastic disorders. 
be used as an effective vector after targeted deletion of its vaccinia growth factor $(V G F)$ and $T K$ genes.$^{57}$ Delivery of p53, $I L-2$, and $I L-12$ in a combined synergistic treatment has shown inhibition of glioma growth in mice..$^{14}$

Retroviruses are unique since they use reverse transcriptase to convert their genetic information into DNA before being integrated into the host genome. Retrovirus vectors have been mainly used to deliver suicide genes to cancer cells, which have shown to increase cell vulnerability to chemotherapeutic agents and induce cell apoptosis. ${ }^{18} \mathrm{HSV}-T K$ has been delivered to tumor cells via retroviruses, increasing cell sensitivity to ganciclovir. ${ }^{78}$

Other viruses that can also be used in gene therapy are the Newcastle disease virus, reoviruses, vesicular stomatitis virus, poliovirus, and the measles virus. Additionally, not all viral vectors are created equal. ${ }^{81}$ For instance, adenoviruses are able to transduce nondividing and dividing cells and carry up to $8 \mathrm{Kbp}$ of heterologous DNA, but they are highly immunogenic. HSV is well suited as an oncolytic virus and can carry up to $50 \mathrm{Kbp}$ of heterologous DNA, but it poses the risk of residual cytotoxicity and most humans have partial immunity against it.

Another gene therapy strategy that can be applied is using stem cells as oncolytic virus carriers. ${ }^{61}$ An advantage to this method is that viruses can be dispensed intravascularly, thus evading antiviral immunity and being able to reach the tumor from a distance. Mesenchymal stromal cells loaded with Ad- $\Delta 24$ RGD have been able to migrate to and infect intracerebral gliomas, whereas Ad$\Delta 24 \mathrm{RGD}$ alone was unable to do so. ${ }^{87}$

\section{Current Standing of Genetics-Based Treatments for Intracranial Meningiomas}

Meningiomas are the second most common primary intracranial tumor, comprising approximately $30 \%$ of CNS primary neoplasms. ${ }^{27}$ For over 100 years the treatment of choice has been complete resection, but unfortunately this cannot always be achieved. Recurrence rates of meningiomas are high, and we are just beginning to understand the molecular genetics that drive these tumors.

Compared with GBM, little work has been done on clarifying the genetic basis for meningiomas. Only a few gene expression studies, including one genome-wide association study, have been performed to date..$^{23,29,84}$ A literature review of the most relevant studies revealed numerous attempts of gene therapy for meningiomas in the last 17 years (Table 4). Gene therapy strategies that have been employed include wild-type gene insertion, oncolytic virus use, using plasmids to transfer small interfering RNA (siRNA) to meningiomas, and other strategies. Although some studies have shown promising results, virtually none have been applied to clinical trials.

In 1998, Chauvet et al. used a replication-defective adenovirus bearing the Escherichia coli $\beta$-galactosidase gene $(L a c Z)$ to selectively transduce a primary canine meningioma. ${ }^{13}$ The adenovirus was rendered replicationdefective by replacing the early viral regions E1A and E1B with the LacZ gene. A 14-year-old, 8-kg female West Highland Terrier with an olfactory groove meningioma was selected as a candidate for viral injection. The recom- binant virus was injected directly into tumor vessels, and 5 days later, tumor tissue was assessed for viral gene delivery with X-Gal staining. No viral-related cytotoxicity was found, and the study demonstrated that meningiomas could be efficaciously transduced with adenovirus vectors.

In 1999, Ikeda et al. tested the viability of gene therapy by transferring a wild-type $N F 2$ gene into both $N F 2$-positive and NF2-negative human meningioma cells in vitro. ${ }^{39}$ The study compared HSV, adenovirus, and retrovirus vectors, and found that HSV-mediated NF2 gene transfer lead to overexpression of the NF2 product in target cells, which lead to a statistically significant inhibition of meningioma cell proliferation.

Shu et al. constructed a recombinant adenovirus with a mutant $\mathrm{Ha}$-rasN17 gene, which is a Ras pathway inhibitor. ${ }^{74}$ Meningioma cells were infected with this virus in vitro, and cell proliferation was measured labeling and detection assays. Suppression of Ras proteins in meningioma cells inhibited proliferation of all exponentially growing cells.

Dirven et al. investigated whether adenoviruses could continue to be effectively used for gene transfer to meningioma cells in vitro. ${ }^{22} \mathrm{~A}$ recombinant adenovirus expressing the luciferase gene was found to bind to meningioma cells expressing Coxsackievirus and adenovirus receptor (CAR), endothelial growth factor receptor (EGFR), and alpha integrins (ITGAVs). Targeting of adenoviruses to EGFR and ITGAVs was accomplished through the use of bispecific single-chain antibodies and an RGD (arginineglycine-aspartic acid) sequence, respectively. Luciferase gene transfer was increased 3- and 9-fold when the adenovirus was targeted to EGFR and ITGAVs, respectively.

The use of oncolytic viruses for meningioma treatment has also been investigated. Grill et al. modified an adenovirus to replicate selectively in retinoblastoma-mutant cells, showing significant oncolytic activity in benign, atypical, and malignant meningiomas in vitro. ${ }^{32}$ The adenovirus strain that was used was generated through replacement of the gp-19k open reading frame in E3 with the luciferase gene. Yazaki et al. engineered an HSV that inhibited cell growth considerably in higher-grade meningiomas in mice. ${ }^{86}$ This strain of HSV, termed G207, had deletions at both $\gamma 34.5$ loci, which are required for replication in brain tissue and encephalitis pathogenesis; the LacZ gene was also added.

Tummalapalli et al. used plasmid vectors to transfect siRNA constructs for cathepsin B and MMP-9 both in vitro and in vivo. ${ }^{79}$ Compared with controls, meningioma cells treated with bicistronic siRNA plasmids showed decreased migration and invasion.

In 2011, Gupta et al. also used plasmid vectors to transfect siRNA constructs for uPAR/cathepsin B and UPA/UPAR; the authors studied the effect of the constructs on meningioma cells, using them alone as well as in combination with radiation. ${ }^{33}$ Small interfering RNA (siRNA), also known as "silencing RNA," interferes with gene expression, particularly with complementary nucleotide sequences. In this study, siRNA was able to interfere with both uPAR/cathepsin B and UPA/uPAR, which are proteolytic pathways of the urokinase-type plasminogen activator system. These systems have been found to be in- 
R. De la Garza-Ramos et al.

TABLE 4: Literature review of accomplishments in gene therapy for intracranial meningiomas

\begin{tabular}{|c|c|c|c|c|}
\hline Authors \& Year & Gene Therapy Strategy & Vector & Study Type & Result \\
\hline Yazaki et al., 1995 & oncolytic viruses & HSV & in vivo (mice) & inhibition of meningioma cell growth \\
\hline Chauvet et al., 1998 & wild-type LacZ gene insertion & $\mathrm{Ad}$ & in vivo (dog) & effective $L a c Z$ transduction \\
\hline Ikeda et al., 1999 & wild-type NF2 gene insertion & HSV, Ad, retrovirus & in vitro & inhibition of meningioma cell proliferation \\
\hline Shu et al., 1999 & $\begin{array}{l}\text { wild-type Ha-rasN17 gene } \\
\text { insertion }\end{array}$ & $\mathrm{Ad}$ & in vitro & inhibition of meningioma cell proliferation \\
\hline Dirven et al., 2002 & $\begin{array}{l}\text { wild-type luciferase gene } \\
\text { insertion }\end{array}$ & $\mathrm{Ad}$ & in vitro & effective luciferase gene transfer \\
\hline Grill et al., 2005 & oncolytic viruses & $\mathrm{Ad}$ & in vitro & inhibition of meningioma cell proliferation \\
\hline Tummalapalli et al., 2007 & siRNA transfer & plasmid & in vitro/in vivo (mice) & $\begin{array}{l}\text { decreased migration \& invasion of meningioma } \\
\text { cells }\end{array}$ \\
\hline Gupta et al., 2011 & siRNA transfer & plasmid & in vitro/in vivo (mice) & decreased angiogenesis in meningioma \\
\hline
\end{tabular}

volved in meningioma tumorigenesis, via increasing the expression of angiogenic molecules such as Ang-1, Ang-2 and VEGF. Both constructs were able to reduce angiogenesis compared with controls, both in vitro and in vivo.

\section{Frontiers}

Gene therapy is a potential treatment option for meningiomas that is still in development. Even though replication-defective and oncolytic viruses have been investigated as potential vectors in gene therapy for meningiomas, and the NF2 gene has already been transferred to meningioma cells in vitro, there have not been any clinical trials to date. Other potential gene therapy strategies (Fig. 2), such as insertion of the MDRl gene or selective inhibition of oncogenes, have not been fully explored.

The most important limitation in gene therapy for meningiomas is that the molecular and genetic basis of tumorigenesis, progression, and malignancy is not yet fully understood. Although molecular analyses have begun to uncover the roles that tumor suppressor genes, oncogenes, and signaling pathways play in the biology of meningiomas, more research is needed in the form of large-scale genome-wide association studies and high-throughput sequencing. ${ }^{65}$ At the same time, safe and effective gene transfer methods must also be research topics. Two clini- cal trials on gene therapy for GBM failed due to a very poor rate of gene delivery to tumor cells. ${ }^{67,69}$

It must not be forgotten that cancer is a very complex disease and is oftentimes the result of multiple mutations and genetic aberrations. Gene transfer into each individual cancer cell is virtually impossible, so research should also be focused on the transfer of genes encoding therapeutic proteins (including apoptosis-inducing proteins, ${ }^{73}$ immunostimulatory factors,,$^{25,52}$ and prodrug-activating enzymes ${ }^{46}$ ) that attack tumors as a whole and not only individual cells. Gene therapy must not be idealized as a single-therapy alternative but visualized as part of a strategic combination that has the ultimate goal of working synergistically to best treat a patient.

\section{Acknowledgment}

We would like to thank Cecilia I. De la Garza-Ramos for helping with the illustration in Fig. 2.

\section{Disclosure}

The authors report no conflict of interest concerning the materials or methods used in this study or the findings specified in this paper.

Author contributions to the study and manuscript preparation include the following. Conception and design: Caro-Osorio, De

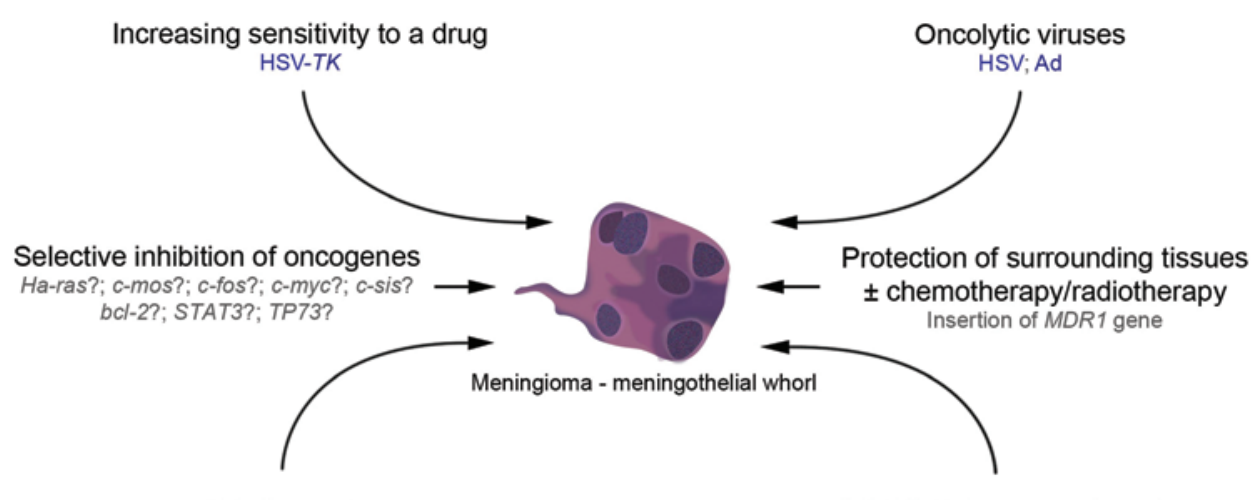

SiRNA transfer

GAT/Wild-type gene insertion NF2; Ha-rasN17; TIMPS?; CDKN2A/CDKN2B?

FIG. 2. Current and potential gene therapy strategies for meningiomas. 
la Garza-Ramos. Acquisition of data: De la Garza-Ramos, FloresRodríguez, Martínez-Gutiérrez, Ruiz-Valls. Analysis and interpretation of data: all authors. Drafting the article: De la Garza-Ramos. Critically revising the article: all authors. Reviewed submitted version of manuscript: all authors. Approved the final version of the manuscript on behalf of all authors: Caro-Osorio. Study supervision: Caro-Osorio.

\section{References}

1. Abramovich CM, Prayson RA: Apoptotic activity and bcl-2 immunoreactivity in meningiomas. Association with grade and outcome. Am J Clin Pathol 114:84-92, 2000

2. Aghi M, Chiocca EA: Gene therapy for glioblastoma. Neurosurg Focus 20(4):E18, 2006

3. Alexiou GA, Markoula S, Gogou P, Kyritsis AP: Genetic and molecular alterations in meningiomas. Clin Neurol Neurosurg 113:261-267, 2011

4. Assi H, Candolfi M, Baker G, Mineharu Y, Lowenstein PR, Castro MG: Gene therapy for brain tumors: basic developments and clinical implementation. Neurosci Lett 527:71-77, 2012

5. Balachandran S, Porosnicu M, Barber GN: Oncolytic activity of vesicular stomatitis virus is effective against tumors exhibiting aberrant $\mathrm{p} 53$, Ras, or myc function and involves the induction of apoptosis. J Virol 75:3474-3479, 2001

6. Barski D, Wolter M, Reifenberger G, Riemenschneider MJ: Hypermethylation and transcriptional downregulation of the TIMP3 gene is associated with allelic loss on 22q12.3 and malignancy in meningiomas. Brain Pathol 20:623-631, 2010

7. Berkner KL: Development of adenovirus vectors for the expression of heterologous genes. Biotechniques 6:616-629, 1988

8. Bickerstaff ER, Small JM, Guest IA: The relapsing course of certain meningiomas in relation to pregnancy and menstruation. J Neurol Neurosurg Psychiatry 21:89-91, 1958

9. Boström J, Meyer-Puttlitz B, Wolter M, Blaschke B, Weber RG, Lichter P, et al: Alterations of the tumor suppressor genes CDKN2A (p16(INK4a)), p14(ARF), CDKN2B (p15(INK4b)), and CDKN2C (p18(INK4c)) in atypical and anaplastic meningiomas. Am J Pathol 159:661-669, 2001

10. Boulaiz H, Marchal JA, Prados J, Melguizo C, Aránega A: Non-viral and viral vectors for gene therapy. Cell Mol Biol (Noisy-le-grand) 51:3-22, 2005

11. Cameron JM, McDougall I, Marsden HS, Preston VG, Ryan DM, Subak-Sharpe JH: Ribonucleotide reductase encoded by herpes simplex virus is a determinant of the pathogenicity of the virus in mice and a valid antiviral target. J Gen Virol 69: 2607-2612, 1988

12. Chamberlain MC: The role of chemotherapy and targeted therapy in the treatment of intracranial meningioma. Curr Opin Oncol 24:666-671, 2012

13. Chauvet AE, Kesava PP, Goh CS, Badie B: Selective intraarterial gene delivery into a canine meningioma. J Neurosurg 88: 870-873, 1998

14. Chen B, Timiryasova TM, Andres ML, Kajioka EH, Dutta-Roy $\mathrm{R}$, Gridley DS, et al: Evaluation of combined vaccinia virusmediated antitumor gene therapy with p53, IL-2, and IL-12 in a glioma model. Cancer Gene Ther 7:1437-1447, 2000

15. Chiocca EA: Oncolytic viruses. Nat Rev Cancer 2:938-950, 2002

16. Choy W, Kim W, Nagasawa D, Stramotas S, Yew A, Gopen Q, et al: The molecular genetics and tumor pathogenesis of meningiomas and the future directions of meningioma treatments. Neurosurg Focus 30(5):E6, 2011

17. Cuevas IC, Slocum AL, Jun P, Costello JF, Bollen AW, Riggins GJ, et al: Meningioma transcript profiles reveal deregulated Notch signaling pathway. Cancer Res 65:5070-5075, 2005

18. Cutter JL, Kurozumi K, Chiocca EA, Kaur B: Gene therapeu- tics: the future of brain tumor therapy? Expert Rev Anticancer Ther 6:1053-1064, 2006

19. De Laporte L, Cruz Rea J, Shea LD: Design of modular nonviral gene therapy vectors. Biomaterials 27:947-954, 2006

20. Detta A, Kenny BG, Smith C, Logan A, Hitchcock E: Correlation of proto-oncogene expression and proliferation and meningiomas. Neurosurgery 33:1065-1074, 1993

21. Diedrich U, Eckermann O, Schmidtke J: Rare Ha-ras and cmos alleles in patients with intracranial tumors. Neurology 38:587-589, 1988

22. Dirven CM, Grill J, Lamfers ML, Van der Valk P, Leonhart AM, Van Beusechem VW, et al: Gene therapy for meningioma: improved gene delivery with targeted adenoviruses. J Neurosurg 97:441-449, 2002

23. Dobbins SE, Broderick P, Melin B, Feychting M, Johansen $\mathrm{C}$, Andersson U, et al: Common variation at 10p12.31 near MLLT10 influences meningioma risk. Nat Genet 43:825-827, 2011

24. Dorer DE, Nettelbeck DM: Targeting cancer by transcriptional control in cancer gene therapy and viral oncolysis. Adv Drug Deliv Rev 61:554-571, 2009

25. Dranoff G, Jaffee E, Lazenby A, Golumbek P, Levitsky H, Brose K, et al: Vaccination with irradiated tumor cells engineered to secrete murine granulocyte-macrophage colonystimulating factor stimulates potent, specific, and long-lasting anti-tumor immunity. Proc Natl Acad Sci U S A 90:35393543,1993

26. Fan ZX, Shen J, Wu YY, Yu H, Zhu Y, Zhan RY: Hormone replacement therapy and risk of meningioma in women: a metaanalysis. Cancer Causes Control 24:1517-1525, 2013

27. Fathi AR, Roelcke U: Meningioma. Curr Neurol Neurosci Rep 13:337, 2013

28. Fernandez HA, Kallenbach K, Seghezzi G, Grossi E, Colvin $\mathrm{S}$, Schneider R, et al: Inhibition of endothelial cell migration by gene transfer of tissue inhibitor of metalloproteinases-1. J Surg Res 82:156-162, 1999

29. Fèvre-Montange M, Champier J, Durand A, Wierinckx A, Honnorat J, Guyotat J, et al: Microarray gene expression profiling in meningiomas: differential expression according to grade or histopathological subtype. Int J Oncol 35:1395-1407, 2009

30. Gautreau A, Louvard D, Arpin M: ERM proteins and NF2 tumor suppressor: the Yin and Yang of cortical actin organization and cell growth signaling. Curr Opin Cell Biol 14:104109,2002

31. Greenberg MS: Meningiomas, in: Handbook of Neurosurgery, ed 7. New York: Thieme, 2010, pp 613-620

32. Grill J, Lamfers ML, van Beusechem VW, van der Valk P, Huisman A, Sminia P, et al: Oncolytic virotherapy of meningiomas in vitro with replication-competent adenovirus. Neurosurgery 56:146-154, 2005

33. Gupta R, Nalla AK, Gogineni VR, Chetty C, Bhoopathi P, Klopfenstein JD, et al: uPAR/cathepsin B overexpression reverse angiogenesis by rescuing FAK phosphorylation in uPAR/cathepsin B down regulated meningioma. PLoS ONE 6:e17123, 2011

34. Haisma HJ, Grill J, Curiel DT, Hoogeland S, van Beusechem VW, Pinedo HM, et al: Targeting of adenoviral vectors through a bispecific single-chain antibody. Cancer Gene Ther 7:901904, 2000

35. Halaka AN, Bunning RA, Bird CC, Gibson M, Reynolds JJ: Production of collagenase and inhibitor (TIMP) by intracranial tumors and dura in vitro. J Neurosurg 59:461-466, 1983

36. Harrison MJ, Wolfe DE, Lau TS, Mitnick RJ, Sachdev VP: Radiation-induced meningiomas: experience at the Mount Sinai Hospital and review of the literature. J Neurosurg 75:564574, 1991

37. Hasseleid BF, Meling TR, Rønning P, Scheie D, Helseth E: Surgery for convexity meningioma: Simpson Grade I resection as the goal. Clinical article. J Neurosurg 117:999-1006, 2012 


\section{R. De la Garza-Ramos et al.}

38. Hottinger AF, Khakoo Y: Neurooncology of familial cancer syndromes. J Child Neurol 24:1526-1535, 2009

39. Ikeda K, Saeki Y, Gonzalez-Agosti C, Ramesh V, Chiocca EA: Inhibition of NF2-negative and NF2-positive primary human meningioma cell proliferation by overexpression of merlin due to vector-mediated gene transfer. J Neurosurg 91:85-92, 1999

40. Jagannathan J, Oskouian RJ, Yeoh HK, Saulle D, Dumont AS: Molecular biology of unreresectable meningiomas: implications for new treatments and review of the literature. Skull Base 18:173-187, 2008

41. Jiang H, Gomez-Manzano C, Lang FF, Alemany R, Fueyo J: Oncolytic adenovirus: preclinical and clinical studies in patients with human malignant gliomas. Curr Gene Ther 9: 422-427, 2009

42. Johnson MD, Okediji E, Woodard A: Transforming growth factor-beta effects on meningioma cell proliferation and signal transduction pathways. J Neurooncol 66:9-16, 2004

43. Kalamarides M, Stemmer-Rachamimov AO, Niwa-Kawakita M, Chareyre F, Taranchon E, Han ZY, et al: Identification of a progenitor cell of origin capable of generating diverse meningioma histological subtypes. Oncogene 30:2333-2344, 2011

44. Kazumoto K, Tamura M, Hoshino H, Yuasa Y: Enhanced expression of the sis and c-myc oncogenes in human meningiomas. J Neurosurg 72:786-791, 1990

45. Kesari S, Randazzo BP, Valyi-Nagy T, Huang QS, Brown SM, MacLean AR, et al: Therapy of experimental human brain tumors using a neuroattenuated herpes simplex virus mutant. Lab Invest 73:636-648, 1995

46. Kievit E, Bershad E, Ng E, Sethna P, Dev I, Lawrence TS, et al: Superiority of yeast over bacterial cytosine deaminase for enzyme/prodrug gene therapy in colon cancer xenografts. Cancer Res 59:1417-1421, 1999

47. Kim MS, Yu DW, Jung YJ, Kim SW, Chang CH, Kim OL: Long-term follow-up result of hydroxyurea chemotherapy for recurrent meningiomas. J Korean Neurosurg Soc 52:517522,2012

48. Knudson AG Jr: Mutation and cancer: statistical study of retinoblastoma. Proc Natl Acad Sci U S A 68:820-823, 1971

49. Lang FF, Bruner JM, Fuller GN, Aldape K, Prados MD, Chang S, et al: Phase I trial of adenovirus-mediated p53 gene therapy for recurrent glioma: biological and clinical results. J Clin Oncol 21:2508-2518, 2003

50. Lavertu M, Méthot S, Tran-Khanh N, Buschmann MD: High efficiency gene transfer using chitosan/DNA nanoparticles with specific combinations of molecular weight and degree of deacetylation. Biomaterials 27:4815-4824, 2006

51. Lee Y, Liu J, Patel S, Cloughesy T, Lai A, Farooqi H, et al: Genomic landscape of meningiomas. Brain Pathol 20:751-762, 2010

52. Li CY, Huang Q, Kung HF: Cytokine and immuno-gene therapy for solid tumors. Cell Mol Immunol 2:81-91, 2005

53. Louis DN, Ohgaki H, Wiestler OD, Cavenee WK, Burger PC, Jouvet A, et al: The 2007 WHO classification of tumours of the central nervous system. Acta Neuropathol 114:97-109, 2007

54. Lusis EA, Watson MA, Chicoine MR, Lyman M, Roerig P, Reifenberger $\mathrm{G}$, et al: Integrative genomic analysis identifies NDRG2 as a candidate tumor suppressor gene frequently inactivated in clinically aggressive meningioma. Cancer Res 65: 7121-7126, 2005

55. Martuza RL, Malick A, Markert JM, Ruffner KL, Coen DM: Experimental therapy of human glioma by means of a genetically engineered virus mutant. Science 252:854-856, 1991

56. Maxwell M, Galanopoulos T, Hedley-Whyte ET, Black PM, Antoniades HN: Human meningiomas co-express plateletderived growth factor (PDGF) and PDGF-receptor genes and their protein products. Int J Cancer 46:16-21, 1990

57. McCart JA, Ward JM, Lee J, Hu Y, Alexander HR, Libutti SK, et al: Systemic cancer therapy with a tumor-selective vaccinia virus mutant lacking thymidine kinase and vaccinia growth factor genes. Cancer Res 61:8751-8757, 2001
58. Mercer WE, Shields MT, Amin M, Sauve GJ, Appella E, Romano JW, et al: Negative growth regulation in a glioblastoma tumor cell line that conditionally expresses human wild-type p53. Proc Natl Acad Sci U S A 87:6166-6170, 1990

59. Mineta T, Rabkin SD, Yazaki T, Hunter WD, Martuza RL: Attenuated multi-mutated herpes simplex virus-1 for the treatment of malignant gliomas. Nat Med 1:938-943, 1995

60. Moriuchi S, Glorioso JC, Maruno M, Izumoto S, Wolfe D, Huang S, et al: Combination gene therapy for glioblastoma involving herpes simplex virus vector-mediated codelivery of mutant IkappaBalpha and HSV thymidine kinase. Cancer Gene Ther 12:487-496, 2005

61. Murphy AM, Rabkin SD: Current status of gene therapy for brain tumors. Transl Res 161:339-354, 2013

62. Nettelbeck DM, Miller DW, Jérôme V, Zuzarte M, Watkins SJ, Hawkins RE, et al: Targeting of adenovirus to endothelial cells by a bispecific single-chain diabody directed against the adenovirus fiber knob domain and human endoglin (CD105). Mol Ther 3:882-891, 2001

63. Nunes F, Shen Y, Niida Y, Beauchamp R, Stemmer-Rachamimov AO, Ramesh V, et al: Inactivation patterns of NF2 and DAL-1/4.1B (EPB41L3) in sporadic meningioma. Cancer Genet Cytogenet 162:135-139, 2005

64. Pérez-Magán E, Rodríguez de Lope A, Ribalta T, Ruano Y, Campos-Martín Y, Pérez-Bautista G, et al: Differential expression profiling analyses identifies downregulation of $1 \mathrm{p}$, $6 \mathrm{q}$, and $14 \mathrm{q}$ genes and overexpression of $6 \mathrm{p}$ histone cluster 1 genes as markers of recurrence in meningiomas. Neuro Oncol 12:1278-1290, 2010

65. Pham MH, Zada G, Mosich GM, Chen TC, Giannotta SL, Wang K, et al: Molecular genetics of meningiomas: a systematic review of the current literature and potential basis for future treatment paradigms. Neurosurg Focus 30(5):E7, 2011

66. Pollock BE, Stafford SL, Link MJ, Brown PD, Garces YI, Foote RL: Single-fraction radiosurgery of benign intracranial meningiomas. Neurosurgery 71:604-613, 2012

67. Puumalainen AM, Vapalahti M, Agrawal RS, Kossila M, Laukkanen J, Lehtolainen P, et al: Beta-galactosidase gene transfer to human malignant glioma in vivo using replication-deficient retroviruses and adenoviruses. Hum Gene Ther 9:1769-1774, 1998

68. Ragel BT, Jensen RL: Molecular genetics of meningiomas. Neurosurg Focus 19(5):E9, 2005

69. Rainov NG: A phase III clinical evaluation of herpes simplex virus type 1 thymidine kinase and ganciclovir gene therapy as an adjuvant to surgical resection and radiation in adults with previously untreated glioblastoma multiforme. Hum Gene Ther 11:2389-2401, 2000

70. Randazzo BP, Kesari S, Gesser RM, Alsop D, Ford JC, Brown SM, et al: Treatment of experimental intracranial murine melanoma with a neuroattenuated herpes simplex virus 1 mutant. Virology 211:94-101, 1995

71. Riemenschneider MJ, Perry A, Reifenberger G: Histological classification and molecular genetics of meningiomas. Lancet Neurol 5:1045-1054, 2006

72. Rohringer M, Sutherland GR, Louw DF, Sima AA: Incidence and clinicopathological features of meningioma. J Neurosurg 71:665-672, 1989

73. Seol JY, Park KH, Hwang CI, Park WY, Yoo CG, Kim YW, et al: Adenovirus-TRAIL can overcome TRAIL resistance and induce a bystander effect. Cancer Gene Ther 10:540-548, 2003

74. Shu J, Lee JH, Harwalkar JA, Oh-Siskovic S, Stacey DW, Golubić M: Adenovirus-mediated gene transfer of dominant negative Ha-Ras inhibits proliferation of primary meningioma cells. Neurosurgery 44:579-588, 1999

75. Simon M, Boström JP, Hartmann C: Molecular genetics of meningiomas: from basic research to potential clinical applications. Neurosurgery 60:787-798, 2007 


\section{Genetics-based treatments for meningiomas}

76. Strachan T, Read AP: Gene therapy and other molecular genetic-based therapeutic approaches, in: Human Molecular Genetics, ed 2. New York: Garland Science, 2010 (http://www. ncbi.nlm.nih.gov/books/NBK7569/) [Accessed October 21, 2013]

77. Striedinger K, VandenBerg SR, Baia GS, McDermott MW, Gutmann DH, Lal A: The neurofibromatosis 2 tumor suppressor gene product, merlin, regulates human meningioma cell growth by signaling through YAP. Neoplasia 10:1204-1212, 2008

78. Takamiya Y, Short MP, Moolten FL, Fleet C, Mineta T, Breakefield $\mathrm{XO}$, et al: An experimental model of retrovirus gene therapy for malignant brain tumors. J Neurosurg 79:104-110, 1993

79. Tummalapalli P, Spomar D, Gondi CS, Olivero WC, Gujrati M, Dinh DH, et al: RNAi-mediated abrogation of cathepsin B and MMP-9 gene expression in a malignant meningioma cell line leads to decreased tumor growth, invasion and angiogenesis. Int J Oncol 31:1039-1050, 2007

80. van Alkemade H, de Leau M, Dieleman EM, Kardaun JW, van Os R, Vandertop WP, et al: Impaired survival and long-term neurological problems in benign meningioma. Neuro Oncol 14:658-666, 2012

81. Vannucci L, Lai M, Chiuppesi F, Ceccherini-Nelli L, Pistello M: Viral vectors: a look back and ahead on gene transfer technology. New Microbiol 36:1-22, 2013

82. Wang W, Li W, Ma N, Steinhoff G: Non-viral gene delivery methods. Curr Pharm Biotechnol 14:46-60, 2013

83. Wellenreuther R, Kraus JA, Lenartz D, Menon AG, Schramm $\mathrm{J}$, Louis DN, et al: Analysis of the neurofibromatosis 2 gene reveals molecular variants of meningioma. Am J Pathol 146: 827-832, 1995

84. Wrobel G, Roerig P, Kokocinski F, Neben K, Hahn M, Reifen- berger G, et al: Microarray-based gene expression profiling of benign, atypical and anaplastic meningiomas identifies novel genes associated with meningioma progression. Int J Cancer 114:249-256, 2005

85. Yamada Y, Kimura H, Morishima T, Daikoku T, Maeno K, Nishiyama Y: The pathogenicity of ribonucleotide reductasenull mutants of herpes simplex virus type 1 in mice. J Infect Dis 164:1091-1097, 1991

86. Yazaki T, Manz HJ, Rabkin SD, Martuza RL: Treatment of human malignant meningiomas by G207, a replication-competent multimutated herpes simplex virus 1 . Cancer Res 55: 4752-4756, 1995

87. Yong RL, Shinojima N, Fueyo J, Gumin J, Vecil GG, Marini FC, et al: Human bone marrow-derived mesenchymal stem cells for intravascular delivery of oncolytic adenovirus Delta24-RGD to human gliomas. Cancer Res 69:8932-8940, 2009

88. Zhang MX, Zhao X, Wang ZG, Zhao WM, Wang YS: Constitutive activation of signal transducer and activator of transcription 3 regulates expression of vascular endothelial growth factor in human meningioma differentiation. J Cancer Res Clin Oncol 136:981-988, 2010

Manuscript submitted July 30, 2013.

Accepted August 28, 2013.

Please include this information when citing this paper: DOI: 10.3171/2013.8.FOCUS13305.

Address correspondence to: Enrique Caro-Osorio, M.D., Institute of Neurology and Neurosurgery, Hospital Zambrano Hellion, Tec Salud, Batallón de San Patricio \#112 Real San Agustín, 8th Floor, San Pedro Garza García, Nuevo León 66278, México. email: ecaro@itesm.mx. 